\title{
METODE BUZZ GROUP DISCUSSION DENGAN PERMAINAN ROLET MEMBENTUK KEMAMPUAN KERJASAMA DAN KEMAMPUAN MEMECAHKAN MASALAH PADA MATA PELAJARAN IPS
}

\author{
Syifana, Cut Dhien N, Zaharah, M.Arif \\ zaharah@uinjkt.ac.id \\ (Fakultas Ilmu Tarbiyah dan Keguruan UIN Syarif Hidayatullah Jakarta)
}

\begin{abstract}
Abstrak
Metode buzz group discussion dengan permainan rolet adalah metode pembelajaran diskusi yang dikombinasikan dengan media pembelaran rolet bertujuan untuk melatih siswa dalam berdiskusi, bertukar pendapat dengan teman sekelompoknya, mengemukakan ide-ide terkait materi diskusi dan membuat pembelajaran menjadi aktif dan menyenangkan. Metode penelitian ini menggunakan Quasi Eksperimen terdiri dari kelas kontrol dan kelas eksperimen yang ditentukan berdasarkan purposive sampling yaitu berdasarkan pertimbangan tertentu. Kelas VIII-2 sebagai kelas eksperimen mendapat perlakuan metode buzz group discussion dengan permainan rolet dan kelas VIII-1 tidak mendapat perlakuan metode buzz group discussion dengan permainan rolet. Instrumen pada penelitian ini adalah lembar observasi dan tes. Penelitian menunjukkan bahwa metode buzz group discussion dengan permainan rolet berpengaruh terhadap kemampuan kerjasama dan kemampuan memecahkan masalah siswa kelas VIII SMP Islam Al-Hikmah.
\end{abstract}

Kata Kunci: Metode Buzz Group Discussion, Permainan Rolet, Pembelajaran IPS.

\section{A. Pendahuluan}

Muatan materi IPS yang sangat padat membuat siswa malas belajar dan merasa bosan karena banyak materi yang harus dihafalkan. Hal ini mengakibatkan siswa kesulitan dalam memahami muatan materi pada mata pelajaran IPS. Proses pembelajaran mata pelajaran IPS di kelas masih kurang maksimal karena guru cenderung menjelaskan materi pembelajaran IPS secara kontekstual dan metode yang digunakan dalam proses belajar mengajar masih menggunakan metode konvensional. Hal ini mengakibatkan siswa cenderung pasif dalam kegiatan pembelajaran IPS.

Berdasarkan hasil observasi kegiatan proses pembelajaran IPS di kelas VIII SMP Islam Al-Hikmah pada hari Rabu tanggal 15 Agustus 2018, proses pembelajaran IPS di kelas lebih dominan menggunakan metode ceramah dibandingkan metode pembelajaran kelompok. Metode ceramah tidak dapat dihilangkan dalam proses pembelajaran di kelas. Guru memberikan latihan soal analisis kepada siswa hanya beberapakali pada proses pembelajaran. Kemampuan siswa dalam memecahkan masalah masih kurang. Hal ini dibuktikan sebagian siswa memiliki nilai ulangan mata pelajaran IPS dibawah KKM. Kerjasama antarsiswa juga masih rendah karena proses pembelajaran dikelas cenderung menggunakan metode ceramah dan strategi teacher center.

Pembelajaran berbasis kelompok pernah dilakukan oleh guru tetapi tidak dominan dilakukan setiap hari dalam proses kegiatan pembelajaran. Hal ini membuat sikap siswa lebih cenderung pasif di kelas karena pembelajaran lebih cenderung teacher center. Muatan materi IPS yang padat dan banyak membuat siswa cenderung jenuh dan bosan. Dalam hal ini 
Pembelajaran berbasis kelompok merupakan alternatif untuk membuat siswa menjadi aktif dan dapat mengembangkan pengetahuan siswa, meningkatkan kerjasama dalam mengerjakan tugas kelompok dalam proses pembelajaran dan memberikan pemikiran kritis siswa dalam memecahakan masalah yang diberikan Salah satu metode pembelajaran yang membuat siswa aktif dalam belajar adalah metode buzz group discussion.

Metode pembelajaran buzz group discussion adalah metode pembelajaran yang digunakan dalam kegiatan pembelajaran pemecahan masalah yang dilakukan melalui diskusi di dalam kelompok-kelompok kecil (3-4 orang). Kelompok-kelompok kecil itu melakukan kegiatan diskusi dalam waktu singkat tentang bagian-bagian khusus dari masalah yang dihadapi oleh kelompok besar. ${ }^{1}$ Metode pembelajaran buzz group discussion sebagai alternatif pembelajaran aktif yang relevan untuk pembelajaran IPS. Metode pembelajaran buzz group discussion juga merupakan metode diskusi kelompok yang dapat meningkatkan keaktifan siswa dalam berdiskusi, berpendapat, dan bertanya di dalam kelas. Pemberian metode pembelajaran lebih baiknya dipadukan dengan pemberian media pembelajaran sesuai kebuutuhan. Pemberian media pembelajaran yang baik yaitu media pembelajaran yang dapat menunjang proses pembelajaran di kelas berlangsung dengan baik dan kondusif. Dalam penelitian ini, peneliti menambahkan adanya media pembelajaran rolet yang akan dikombinasikan dengan metode pembelajaran buzz group discussion.

${ }^{1}$ Gede Surjana, Nyoman Garminah, Luh Putu Putrini Mahadewi, “ Pengaruh Teknik Buzz Group terhadap Aktivitas Belajar dan Hasil Belajar Siswa IPS SD", Jurnal Mimbar PGSD Universitas Pendidikan Ganesha, Jurusan PGSD, Vol.2 No.1, 2014, h. 4
Metode pembelajaran buzz group discussion adalah metode diskusi biasa, oleh karena itu peneliti tertarik untuk mengembangkan model buzz group discussion dengan menambahkan media pembelajaran permainan rolet. Rolet adalah Rolet adalah permainan yang menggunakan peluru-peluru kecil diatas papan bulat yang berputar disertai dengan angka-angka atau gambar-gambar. Di dalam penelitian ini, peneliti akan membuat rolet yang berkaitan dengan materi pembelajaran IPS yaitu tentang konflik dan integrasi. Dengan adanya permainan rolet didalam metode buzz group discussion akan membuat suanasa proses pembelajaran menjadi aktif dan menyenangkan.

Berdasarkan Permasalahan diatas terkait dengan pembelajaran IPS, maka peneliti tertarik untuk meneliti judul “ Pengaruh Metode Buzz Group Discussion dengan Permainan Rolet terhadap Kemampuan Kerjasama dan Kemampuan Memecahkan Masalah Siswa pada Mata Pelajaran IPS Kelas VIII di SMP Islam AlHikmah".

\section{B. Rumusan Masalah}

Berdasarkan pendahuluan yang telah diuraikan di atas, masalah yang akan diteliti dalam penelitian ini adalah sebagai berikut :

1. Bagaimanakah pengaruh metode buzz group discussion dengan permainan rolet terhadap kerjasama siswa pada mata pelajaran IPS kelas VIII di SMP Islam Al-Hikmah?

2. Bagaimanakah pengaruh metode buzz. group discussion dengan permainan rolet terhadap kemampuan memecahkan masalah siswa pada mata pelajaran IPS kelas VIII di SMP Islam AlHikmah? 


\section{Tujuan Penelitian}

Berdasarkan rumusan masalah di atas, maka tujuan dari penelitian ini yaitu:

1. Mengetahui pengaruh metode buzz group discussion dengan permainan rolet terhadap kemampuan kerjasama siswa pada mata pelajaran IPS kelas VIII di SMP Islam Al-Hikmah.

2. Mengetahui pengaruh metode buzz group discussion dengan permainan rolet terhadap kemampuan memecahkan masalah siswa pada mata pelajaran IPS kelas VIII di SMP Islam Al-Hikmah.

\section{Kajian Teori}

\section{Pengertian Belajar}

Menurut Gagne berpendapat bahwa belajar adalah suatu proses suatu individu ataupun kelompok berubah perilakunya sebagai akibat pengalaman yang diperolehnya. Belajar adalah suatu proses seseorang memperoleh motivasi dalam pengetahuan, keterampilan, kebiasaan, dan tingkah laku.

\section{Teori Belajar}

Teori-teori belajar terdiri atas toeri belajar humanistik, teori belajar behavioristik, teori pembelajaran konstruktivisme dan teori belajar kognitif. Penjelasan mengenai macam-macam teori belajar yaitu:

a. Teori belajar behavioristik adalah sebuah teori tentang perubahan tingkah laku manusia sebagai hasil dari suatu pengalaman. Teori ini menekankan pada terbentuknya perilaku sebagai hasil belajar. Teori belajar behaviorisme menurut Harley dan Davis.

b. Teori belajar kognitif menurut Bruner mengemukakan proses pembelajaran akan berjalan dengan baik apabila siswa diberikan kesempatan untuk mempelajari suatu konsep dan teori secara nyata dan berdasarkan kebenaran umum.

c. Teori belajar konstruktivisme adalah teori yang memberikan keaktifan siswa untuk belajar menemukan sendiri kompetensi, pengetahuan, dan hal lain yang dapat mengembangkan dirinya.

d. Teori belajar humanistik adalah sebuah teori yang lebih menekankan pada sisi perkembangan manusia. teori ini melihat bahwa manusia dapat membangun dirinya untuk melakukan hal-hal yang positif.

\section{Metode Pembelajaran}

Menurut Abdurrahman Ginting berpendapat bahwa metode pembelajaran adalah cara yang khas yang dilakukan oleh guru untuk memanfaatkan prinsip dasar pendidikan agar terjadi proses pembelajaran untuk siswa.

\section{Media Pembelajaran}

Media pembelajaran berasal dari bahasa latin yaitu "media" dalam bentuk jamak dari kata "medium"yang berarti perantara atau pengantar, jadi pengertian media pembelajaran adalah alat penyalur informasi dalam proses pembelajaran. Media pembelajaran juga dapat diartikan sebagai alat bantu yang menjadi sumber belajar yang memungkinkan peserta didik memperoleh pengetahuan dan keterampilan.

\section{Metode Pembelajaran Buzz Group Discussion}

Menurut Ausabel, metode pembelajaran buzz group discussion atau pembelajaran kelompok sangat berpengaruh untuk metode pemecahan masalah dan dapat meningkatkan kerjasama siswa. Dalam pembelajaran pemecahan masalah siswa berbagi peran atau tugas dalam kelompoknya untuk menyelesaikan masalah yang diberikan oleh guru. Proses pemecahan masalah 
melibatkan kerjasama siswa dalam kelompok dan juga adanya interaksi siswa dan guru dalam proses pemecahan masalah. $^{2}$

Tujuan pembelajaran buzz group discussion yaitu: Menciptakan suasana pembelajaran yang aktif dan menyenangkan, Melatih siswa dalam mengemukakan pendapat didalam forum diskusi, Mengembangkan pengetahuan siswa dalam menganalisis masalah yang diberikan oleh guru dan Menumbukan antusiasme dan motivasi siswa dalam mencari informasi yang berkaitan dengan topik diskusi. ${ }^{3}$

\section{Permainan Rolet}

Rolet adalah permainan yang menggunakan peluru-peluru kecil diatas papan bulat yang berputar disertai dengan angka-angka atau gambar-gambar. Pengertian lain dari rolet adalah alat dengan sebuah roda yang dilengkapi dengan baris-baris yang berputar disertai dengan angka dan warna. ${ }^{4}$ Permainan rolet yang digunakan untuk peserta didik dimodifikasi sesuai kegiatan pembelajaran yang akan dilakukan guru dikelas dan tidak menggunakan unsur taruhan atau judi sehinggan permainan rolet aman digunakan untuk pembelajaran siswa di kelas. Dengan adanya permainan rolet diharapkan dapat meningkatkan motivasi belajar siswa di kelas. Media Pembelajaran rolet digunakan didalam kelas untuk

\footnotetext{
${ }^{2}$ Gede Surjana, Nyoman Garminah, Luh Putu Putrini Mahadewi, "Pengaruh Teknik Buzz Group terhadap Aktivitas Belajar dan Hasil Belajar Siswa IPS SD", Jurnal Mimbar PGSD Universitas Pendidikan Ganesha, Jurusan PGSD, Vol. 2 No.1, 2014, h. 71

${ }^{3}$ Muhammad Saleh Azis, "Penerapan Metode Buzz Group untuk Meningkatkan Aktivitas dan Hasil Belajar Mahasiswa", Jurnal Matematika, Vol.3, No.2, 2016, h. 70

${ }^{4}$ Tim Redaksi Kamus Bahasa Indonesia, Kamus Bahasa Indonesia, (Jakarta: Pusat Bahasa Dapartemen Pendidikan Nasional, 2008), h. 1217
}

menunjang kegiatan pembelajaran. Aturan permainan rolet yang akan digunakan didalam kelas yaitu:

a. Guru membagi kelas menjadi beberapa kelompok kecil yang beranggotakan 45 orang.

b. Setiap perwakilan kelompok maju ke depan kelas untuk memutar rolet yang sudah disiapkan oleh guru.

c. Setiap kelompok mempunyai kesempatan untuk memutar rolet tiga kali dan mendapat kartu soal dari rolet yang sudah diputarkan oleh siswa.

d. Setiap kelompok harus menjawab soal sesuai kartu soal yang didapat. Kelompok yang jawabannya tepat dan cepat mengerjakan soal akan mendapatkan poin nilai yang diberikan oleh guru.

\section{Kemampuan Kerjasama}

Menurut Isjoni, pembelajaran harus menekankan pada kerjasama dalam kelompok untuk mencapai tujuan yang sama. Pembelajaran yang menekankan pada kerjasama dapat menanamkan keterampilan siswa antara lain yaitu menghargai pendapat orang lain, mendorong berpartisipasi, mendorong untuk bertanya, berani bertanya, dan mengambil giliran untuk berbagi tugas. ${ }^{5}$ Menurut Isjoni Indikator dalam kerjasama ada 5 yaitu: kontribusi setiap anggota kelompok, tanggung jawab setiap anggota kelompok, peyamaan pendapat seluruh anggota, sikap saling membantu sesame angota kelompok, dan Adanya interaksi tatap muka yang dapat meningkatkan sukses satu sama lain diantara anggota.

\section{Kemampuan Memecahkan Masalah}

Menurut Krulik dan Rudnik, masalah adalah suatu kondisi yang sulit yang dialami oleh individu maupun kelompok untuk mencari solusi penyelesaian dari

${ }^{5}$ Ibid, h.44 
masalah tersebut tetapi individu maupun kelompok belum mengetahui solusi untuk memecahkan masalah tersebut. Pemecahan masalah adalah cara atau proses untuk memecahkan masalah. Menurut Gagne, pembelajaran pemecahan masalah adalah proses untuk memahami masalah dengan cara menemukan masalah berkaitan dengan konsep yang sudah dipelajari oleh siswa untuk diaplikasikan atau diterapkan untuk memperoleh solusi untuk menyelesaikan masalah. ${ }^{6}$ Berdasarkan indikator pemecahan masalah menurut Polya, dapat dirumuskan indikator kemampuan pemecahan masalah adalah sebagai berikut : (1) Siswa dapat mengidentifikasi informasi yang diketahui dan ditanyakan dalam soal; (2) Siswa dapat menjelaskan masalah sesuai dengan kalimat sendiri; (3) Siswa harus menyederhanakan masalah; (4) Siswa harus mencari dan mengurutkan informasi untuk menyelesaikan masalah.; (5) Siswa membuat hipotesis untuk menyelesaikan masalah; (6) Siswa melakukan penyelidikin dengan data dan informasi yang diperoleh; (7) Siswa membuat alternatif pemecahan masalah; (8) Siswa melakukan pengujian alternatif solusi untuk pemecahan masalah; (9) Siswa memeriksa kembali kesesuaian semua informasi dan jawaban yang telah dituliskan; (10) Siswa membuat kesimpulan berdasarkan masalah yang diberikan oleh guru. ${ }^{7}$

\footnotetext{
${ }^{6}$ Yufi Nurfitasari, Kartika Chrysti Suryandari, dan Suhartono, "Analisis Kemampuan Kerjasama dalam Pembelajaran IPA (Studi Deskriptif pada Siswa kelas V SD Negeri 4 Kutosari)", Jurnal Inovasi Pendidikan, 2017, h. 227

${ }^{7}$ Hesti Cahyani dan Ririn Wahyu Setyawati, Pentingnya Peningkatan Kemampuan Pemecahan Masalah melalui PBL untuk Mempersiapkan Generasi Unggul Menghadapi MEA, "Seminar Nasional Matematika X Universitas Semarang 2016, 2016, h. 156
}

\section{IPS}

IPS merupakan suatu bidang dalam pengajaran yang ada di sekolah mempunyai tujuan untuk mengembangkan pengetahuan, sikap, dan keterampilan sosial siswa untuk memberikan pengalaman belajar yang ditata untuk studi keilmuan sosial. $^{8}$ Istilah Ilmu Pengetahuan Sosial (IPS) adalah nama mata pelajaran di jenjang sekolah dan di perguruan tinggi nama mata pelajaran IPS lebih identik dengan istilah "Social Studies" terutama di negara-negara barat seperti Australia dan Amerika Serikat.

\section{E. Kerangka Berpikir}

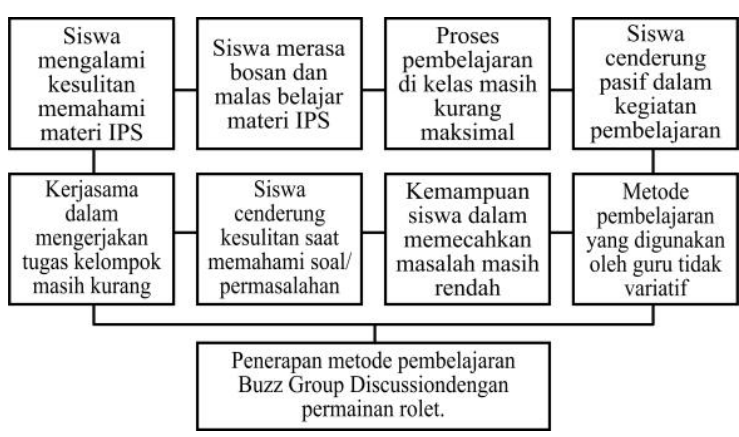

\section{F. Metode Penelitian}

Metode penelitian yang akan digunakan dalam penelitian ini adalah metode penelitian kuasi ekperimen (quasiexperiment) dengan pendekatan penelitian kuantitatif. Penelitian kuasi eksperimen merupakan metode yang tidak memungkinkan peneliti melakukan pengontrolan secara penuh terhadap variabel dan kondisi-kondisi eksperimen. Penelitian kuasi eksperimen merupakan penelitian dengan menggunakan kelompok kontrol dan kelompok eksperimen yang digunakan sebagai objek yang diteliti. Dalam penelitian ini, peneliti ikut serta dalam penelitian yaitu dengan cara mengajar di sekolah.

${ }^{8}$ Huriah Rachman, Pengembangan Profesi Pendidikan IPS, (Bandung: Alfabeta, 2014), h. 52 
Desain atau rancangan dalam penelitian ini adalah Nonequivalent Kontrol Group Design. Nonequivalent Kontrol Group Design yaitu desain penelitian yang mirip dengan Pre-test Post-test Control Group yaitu kelompok eksperimen maupun kelompok kontrol diberi pre-test. kemudian kelompok eksperimen diberikan treatment. Setelahnya maka dilakukan posttest pada kelompok eksperimen dan kelompok kontrol. $^{9} \quad$ Bedanya pada desain Nonequivalent Kontrol Group, kelompok eksperimen maupun kelompok kontrol tidak dipilih secara random. ${ }^{10}$

Pada pelaksanaannya peneliti mengambil sampel 2 kelas yaitu kelas VIII-2 SMP Islam Al-Hikmah sebagai kelas eksperimen dimana mendapatkan perlakuan berupa metode buzz group discussion dengan permainan rolet. Sedangkan kelas VIII-1 SMP Islam AlHikmah sebagai kelas kontrol diberi perlakuan metode konvensional yaitu diskusi. Waktu pelaksanaan penelitian dari bulan Agustus 2018 sampai dengan bulan September 2018.

\section{G. Teknik Pengumpulan Data}

Adapun teknik pengumpulan data yang dilakukan oleh penulis yaitu:

\section{Observasi}

Observasi juga bisa dikatakan sebagai pengumpulan data yang akurat dengan cara mengamati obyek yang akan diteliti. Dalam penelitian ini, dilakukan observasi terhadap proses pembelajaran IPS dan kemampuan kerjasama siswa di kelas kontrol dan kelas eksperimen. Observasi dilakukan untuk mengetahui kemampuan kerjasama siswa di kelas

${ }^{9}$ Erwan Agus Purwanto dan Dyah Ratih Sulistyasturi, Metode Penelitian Kuantitatif untuk Administrasi Publik dan Masalah-masalah Sosial, (Yogyakarta: Gava Media,2017), h. 90

${ }^{10}$ Ibid, h. 91 eksperimen maupun kontrol dan untuk mengetahui kegiatan proses pembelajaran IPS dengan metode buzz group discussion. Observasi yang dilakukan oleh peneliti dalam pencatatanya menggunakan dua alat observasi yaitu:

a. Rating scale. Pencatatan menggunakan rating scale adalah mencatat gejala atau obyek yang akan dimati menurut tingkatannya. Rating scale mempunyai tingkatan nilai dari 1-4 untuk menilai obyek yang akan diamati.Rating Scale digunakan untuk mengamati kerjasama siswa di kelas konrol dan eksperimen.

b. Check lists. Check lists merupakan salah satu pencatatan dalam mengamati obyeknya menggunkan tanda ceklis $(\sqrt{ })$ apabila obyek yang diamati melaksanakan kegiatan sesuai yang penelikti harapkan. Dalam penelitian ini Check lists digunakan untuk megamati kegiatan proses pembelajaran IPS yang ditinjau dari guru di kelas kontrol dan eksperimen. ${ }^{11}$

\section{Tes}

Tes didefinisikan sebagai suatu teknik atau cara untuk mengukur kemampuan siswa dengan adanya pertanyaan, pernyataan atau serangkaian tugas yang harus dikerjakan atau dijawab oleh siswa untuk mengukur aspek kognitif siswa. ${ }^{12}$ Tes ini akan diberikan kepada kelas kontrol dan kelas eksperimen. Siswa akan diberikan tes beupa pre-test dan posttest untuk megukur kemampuan memecahkan masalah siswa pada mata pelajaran IPS di kelas kontrol dan kelas eksperimen. Bentuk soal tes yang akan diberikan kepada siswa yaitu soal essay.

${ }^{11}$ Zaenal Arrifin, Evaluasi Pembelajaran Prinsip, Teknik, dan Prosedur, (Bumi Siliwangi: PT. Remaja Rosdakarya, 2009), h. 164-165

${ }^{12}$ Opcit, h. 118 


\section{Dokumentasi}

Dokumentasi merupakan salah satu pelengkap dari teknik pengumpulan data observasi dan tes yang akan dilakukan oleh peneliti. Dokumentasi dilakukan untuk memperoleh data secara langsung dari tempat penelitian berupa, foto-foto yang relevan dengan kegiatan proses belajar IPS, RPP, dan data pretest dan posstest siswa dalam mata pelajan IPS, dan data profil sekolah.

\section{H. Pembahasan}

1. Pengaruh Metode Buzz Group Discussion terhadap Kemampuan Kerjasama Siswa pada Mata Pelajaran IPS

Berdasarkan nilai rata-rata pretest kerjasama kelas kontrol dan kelas eksperimen mengalami peningkatan. Nilai rata-rata pretest kerjasama siswa pada kelas kontrol yaitu 65,52 dan nilai posttest kerjasama siswa di kelas kontrol sebesar 77. Dari nilai rata-rata pos-ttet tersebut, kelas kontrol mengalami peningkatan yang cukup signifikan dalam kerjasama siswa. Kelas kontrol juga mengalami peningkatan yang sangat signifikan yaitu dari nilai pretest yang rata-rata kerjasamanya sebesar 74, 91 mengalami peningkatan dari nilai post-test kerjasama sebesar 89. Dapat dianalisis bahwa kelas eksperimen mempunyai tingkat nilai rata-rata yang lebih tinggi dibandingkan dengan kelas kontrol.

Metode buzz group discussion mempunyai pengaruh yang tinggi terhadap proses kerjasama siswa dalam diskusi kelompok pada mata pelajaran IPS. Hal ini dibuktikan dari nilai rata-rata posttest kerjasama siswa pada kelas eksperimen. Dalam metode buzz group discussion siswa lebih teratur dalam berdiskusi, dalam pembagian peran tugas lebih rapi dan teratur. Metode buzz group discussion yang dilakukan di kelas eksperimen juga menggunkan permainan rolet sebagai media pembelajaran. Dengan adanya media permainan rolet siswa lebih tertarik dan termotivasi dalam belajar dan proses kegiatan belajar mengajar di kelas menjadi lebih menyenangkan.

\section{Pengaruh Metode Buzz Group Discussion terhadap Kemampuan Memecahkan Masalah Siswa pada Mata Pelajaran IPS}

Berdasarkan hasil data pre-test kemampuan memecahkan masalah siswa dikelas ekperimen dan kelas kontrol yaitu kelas eksperimen mendapatkan nilai rata rata pretest sebesar 69,04 dan kelas kontrol mendapatkan nilai rata-rata pre-test sebesar 63,74. Nilai terendah pre-test yang diperoleh kelas kontrol dan kelas eksperimen sebesar 48. Dari hasil nilai pretest, kelas eksperimen memiliki nilai ratarata yang cukup tinggi dibandingkan kelas kontrol. Pembelajaran pemecahan masalah di kelas eksperimen, memiliki daya analisis yang baik dalam memahami masalah yamg diberikan oleh guu, menjelaskan masalah dengan bahasa sendiri, membuat hipotesis sampai penarikan kesimpulan. Kelas eksperimen dalam kegiatan pembelajarannya menggunakan metode buzz group discussion dengan permainan rolet.

Dalam pembelajaran buzz group discussion, siswa dibagi menjadi 6 kelompok yang terdiri dari 4-5 anggota kelompok dan adanya peran tugas yang akan dijalankan oleh masing-masing kelompok yaitu ketua kelompok, sekertaris atau notulen, dan juru bicara atau presentator. Pembelajaran IPS dikelas eksperimen menggunakan metode buzz group discussion merupakan salah satu alternatif untuk meningkatkan analisis siswa dalam menyelesaikan suatu masalah, dan dapat meningkatkan daya kognitif siswa dalam hasil belajar IPS. Dengan adanya permainan rolet suasana 
pembelajaran menjadi lebih menarik dan menyenangkan.

Pengujian hipotesis dengan uji T-test paired samples diperoleh nilai $\mathrm{t}$ sebesar 4.172 dengan nilai taraf signifikasi (Sig) sebesar $0,000<0,05$ yang berarti memenuhi kriteria pengujian yaitu $(($ Sig. $(2$-tailed $))<0,05$ yaitu $0,000<0,05$ maka $\mathrm{H}_{\mathrm{O}}$ ditolak dan $\mathrm{H}_{1}$ diterima. Dapat ditarik kesimpulan bahwa terdapat pengaruh metode buzz group discussion terhadap kemampuan memecahkan masalah siswa.

\section{Kesimpulan}

Berdasarkan hasil penelitian, kelas eksperimen memiliki nilai posstest kemampuan kerjasama dan kemampuan memecahkan masalah lebih tinggi dibandingkan dengan kelas kontrol sehingga metode buzz group discussion dengan permainan rolet berpengaruh terhadap kemampuan kerjasama dan kemampuan memecahkan masalah siswa kelas VIII pada mata pelajaran IPS di SMP Islam Al-Hikmah. Kelas eksperimen memperoleh nilai rata-rata post-test kemampuan kerjasama sebesar 89 dan kelas kontrol memperoleh nilai 77 . Kelas eksperimen memperoleh nilai rata-rata post-test kemampuan memecahkan masalah sebesar 85 dan kelas kontrol memperoleh nilai 75 .

\section{DAFTAR PUSTAKA}

Ahmadi, Abu, Ilmu-Ilmu Sosial Dasar, Jakarta: Rineka Cipta, 2009

Arifin, Zaenal, Penelitian Pendidikan Metode dan Paradigma, (Bandung: PT Remaja Rosdakarya,2011

Arikunto, Suharsimi, Prosedur Penelitian Suatu Pendekatan Praktik, Jakarta: Rineka Cipta, 2013

Arrifin, Zaenal, Evaluasi Pembelajaran Prinsip, Teknik, dan Prosedur, Bumi
Siliwangi: PT Remaja Rosdakarya, 2009

Arsyad, Azhar, Media Pembelajaran, Jakarta: Rajawali,2011

Azis, Muhammad Saleh, "Penerapan Metode Buzz Group untuk Meningkatkan Aktivitas dan Hasil Belajar Fisika di SMP”, Jurnal Matematika, Vol. 3, No. 2, 2016

Dewi Anjani, Sucita dan Maridi, "Profil Keterampilan Kerjasama dalam Kelompok Siswa Kelas XI SMA Negeri 8 Surakarta pada Materi Sistem Peredaran Darah", Jurnal Seminar Pendidikan Sains II UKSW, 2017

Dyah Puspitasari, Endang Fitriyah Mannan dan Nove E. Variant Anna, "Kerjasama dan Jaringan Perpustakaan Antara IndonesiaMalaysia", Jurnal Pendidikan Perpustakaan, Vol. 1, 2014

Erwan Agus Purwanto dan Dyah Ratih Sulistyasturi, Metode Penelitian Kuantitatif untuk Administrasi Publik dan Masalah-masalah Sosial, Yogyakarta: Gava Media, 2017

Febrianti, Eva Hestiana, "Penerapan Metode Buzz Group dalam Meningkatkan Hasil Belajar Siswa Persamaan Linear Satu Variabel (SPLDV) dan Pertidaksamaan Linear Satu Variabel (PTLSV) Bagi Siswa Kelas VIIA SMPN 3 Kaloran Temanggung Semester dua Tahun ajaran 2015/2016, Jurnal Pendidikan Matematika, 2016.

Gede Surjana, Nyoman Garminah dan Luh Putu Putrini Mahadewi, "Pengaruh Teknik Buzz Group terhadap Aktivitas Belajar dan Hasil Belajar Siswa IPS SD”, Jurnal Mimbar $P G S D$ Universitas Pendidikan Ganesha, Jurusan PGSD, Vol. 2 No. 1,2014 
Metode Buzz Group Discussion dengan Permainan Rolet Membentuk Kemampuan Kerjasama dan Kemampuan Memecahkan Masalah Pada Mata Pelajaran IPS 